\title{
Penerimaan Zakat dan Penurunan Kemiskinan di Aceh: Peran Dana Otonomi Khusus Sebagai Pemoderasi
}

\author{
${ }^{1 *}$ Muliadi, ${ }^{2}$ Khairul Amri \\ ${ }^{1}$ Universitas Syiah Kuala, Banda Aceh, Indonesia \\ ${ }^{2}$ Universitas Islam (UIN) Ar-Raniry, Banda Aceh, Indonesia \\ *Email korenpondensi: muliadi.abi@unsyiah.ac.id
}

\begin{abstract}
This study aims to analyze the effect of the zakat revenue on poverty by using the special autonomy fund (DOK) as a moderating variable. Using panel data of 15 districts from Aceh province from 2011 to 2016, Moderated Regression Analysis (MRA) was used to analyze the functional relationship. The study found that zakat revenue and DOK had a negative and significant effect on poverty reduction. The negative impact of DOK on poverty partially more significant compared to the negative impact of zakat revenue. The existence of DOK does not only play a role as a predictor variable but also moderates the effect of zakat revenue on poverty reduction in Aceh.
\end{abstract}

Keywords: Poverty, Zakat Revenue, Special Autonomy Fund, and Moderated Regression Analysis

\begin{abstract}
Abstrak
Penelitian ini bertujuan untuk menganalisis pengaruh penerimaan zakat terhadap kemiskinan dengan menempatkan dana otonomi khusus (DOK) sebagai variabel pemoderasi. Menggunakan data panel 15 kabupaten kota di Aceh selama periode 2011-2016, Moderated Regression Analysis (MRA) digunakan untuk menganalisis hubungan fungsional tersebut. Penelitian menemukan bahwa penerimaan zakat dan DOK berpengaruh negatif dan signifikan terhadap penurunan kemiskinan. Namun secara parsial dampak negatif DOK terhadap kemiskinan lebih signifikan dibandingkan dengan dampak negatif penerimaan zakat. Keberadaan DOK tidak hanya berperan sebagai predictor variable, tetapi juga memoderasi pengaruh penerimaan zakat terhadap penurunan kemiskinan di Aceh.
\end{abstract}

Kata kunci: Kemiskinan, Penerimaan Zakat, Dana Otonomi Khusus, Moderated Regression Analysis

Saran sitasi: Muliadi., \& Amri, K. (2019). Penerimaan Zakat dan Penurunan Kemiskinan di Aceh: Peran Dana Otonomi Khusus Sebagai Pemoderasi. Jurnal Ilmiah Ekonomi Islam, 5(03), 231-244. doi: http://dx.doi.org/10.29040/jiei.v5i3.706

DOI: $\underline{\text { http://dx.doi.org/10.29040/jiei.v5i3.706 }}$

\section{Pendahuluan}

Aceh merupakan salah satu provinsi dengan tingkat kemiskinan relatif tinggi dibandingkan dengan daerah lainnya di Indonesia. Hingga Maret 2019, jumlah penduduk miskin di daerah ini mencapai 819 ribu jiwa $(15,32 \%)$ dan merupakan daerah dengan kemiskinan tertinggi di Sumatera. Secara nasional Aceh menempati peringkat 6 tertinggi setelah setelah Papua, Papua Barat, Nusa Tenggara Timur, Maluku dan Gorontalo. Sejalan dengan tingginya tingkat kemiskinan, ketimpangan pendapatan di Aceh juga relatif tinggi (Amri, 2017a). Hingga semester kedua 2018 Gini ratio Aceh sebesar 0,322 lebih besar dibandingkan dengan Sumatera Utara (0,315) dan Sumatera Barat $(0,313)$. 
Tingginya tingkat kemiskinan dan ketimpangan pendapatan di Aceh, merupakan tantangan bagi pemerintah Aceh dalam mewujudkan kesejahteraan masyarakat di daerah ini (Amri \& Nazamuddin, 2018). Setiap tahun anggaran pemerintah daerah menyusun program kegiatan pembangunan yang berorientasi pada penurunan tingkat kemiskinan. Selain itu, sebagai daerah yang secara umum penduduknya adalah muslim, upaya pemerintah dalam mengurangi tingkat kemiskinan juga dilakukan melalui pemanfaatan dana zakat. Pemerintah Aceh melembagakan pengelolaan zakat dengan dibentuknya Baitul Mal di tingkat provinsi hingga seluruh kabupaten kota di Aceh (Amri \& Marwiyati, 2019). Hal ini dimaksudkan agar pengelolaan dana zakat dapat dilakukan secara optimal dan terkoordinir dengan baik. Selain berfungsi sebagai pengumpul penerimaan zakat, lembaga tersebut juga menyalurkan dana zakat kepada kelompok miskin dan kelompok masyarakat lainnya (mustahiq) yang benar-benar berhak menerima zakat.

Sebagai daerah otonomi khusus, upaya pengentasan kemiskinan di Aceh juga dilakukan dengan cara mengalokasikan dana otonomi khusus (DOK) untuk membiayai kegiatan pembangunan di tingkat kabupaten kota. Hal ini sangat beralasan mengingat dana tersebut merupakan penerimaan Pemerintah Aceh yang ditujukan untuk membiayai pembangunan dan pemeliharaan infrastruktur, pemberdayaan ekonomi rakyat, pengentasan kemiskinan, serta pendanaan pendidikan, sosial dan kesehatan (UU No. 11 Tahun 2006). Pengelolaan DOK tidak hanya berada di tingkat provinsi, tetapi juga menjadi kewenangan kabupaten kota di Aceh dengan perimbangan $60 \%$ dikelola pemerintah provinsi dan $40 \%$ dikelola oleh pemerintah kabupaten kota. Pengalokasian DOK dalam kegiatan pembangunan baik ditingkat provinsi maupun kabupaten kota diarahkan untuk meningkatkan kesejahteraan masyarakat dan penurunan tingkat kemiskinan.

Selama ini kajian mengenai pengaruh zakat terhadap kemiskinan telah dilakukan para peneliti. Demikian pula halnya dengan pengaruh belanja pemerintah seperti halnya DOK terhadap pengentasan kemiskinan di daerah juga menjadi sorotan peneliti kebijakan publik. Namun hasil kajian yang mereka temukan memberikan kesimpulan yang beragam. Berkaitan dengan dampak zakat terhadap kemiskinan misalnya, penelitian Aisyah (2014) memberikan bukti empiris bahwa dana zakat memiliki peran penting dalam meningkatkan taraf hidup masyarakat miskin. Konsisten dengan temuan tersebut, hasil penelitian Murniati \& Beik (2015) juga menyimpulkan bahwa zakat yang diterima oleh mustahiq dapat meningkatkan pendapatan mereka dan mampu menurunkan tingkat kemiskinan secara umum. Namun, berbeda dengan dua peneliti tersebut, hasil kajian Mubarokah et al. (2017) menyimpulkan bahwa dana zakat hanya meningkatkan pendapatan mustahiq, tetapi tidak berdampak signifikan pada penurunan tingkat kemiskinan.

Temuan penelitian yang berkaitan dengan pengaruh belanja pemerintah dalam bentuk dana DOK terhadap penurunan kemiskinan dan peningkatan kesejahteraan masyarakat juga belum memberikan kesimpulan yang seragam. Hasil kajian Tajuddin et al. (2014) di Sulawesi menemukan bahwa dana alokasi khusus di daerah tersebut berdampak pada pertumbuhan ekonomi dan kesejahteraan masyarakat. Sebaliknya, penelitian Fanggidae et al. (2016) tentang kinerja pembangunan di Papua Barat menyimpulkan bahwa DOK belum memberikan dampak signifikan terhadap penurunan tingkat kemiskinan. Sebelumnya, Soejoto et al. (2015) menemukan bahwa peningkatan dana desentralisasi di Indonesia memiliki dampak positif dan signifikan terhadap belanja publik dan pertumbuhan ekonomi, namun belum mampu menurunkan tingkat kemiskinan.

Temuan empiris yang dikemukakan oleh sejumlah peneliti di atas belum menunjukkan adanya konsistensi kesimpulan mengenai pengaruh zakat dan DOK terhadap penurunan kemiskinan. Hal ini berarti bahwa signifikansi dampak kedua variabel tersebut dalam 
mengurangi kemiskinan masih menjadi pertanyaan terbuka sehingga memerlukan adanya kajian lebih lanjut. Apalagi kajian yang mereka lakukan hanya menjadikan dana zakat dan DOK sebagai predictor variable bagi tingkat kemiskinan. Padahal mengingat DOK merupakan instrumen kebijakan fiskal daerah yang juga bertujuan untuk meningkatkan kesejahteraan masyarakat, maka terbuka peluang untuk menganalisis pengaruh interaksi antara kedua predictor variable tersebut dalam mengurangi jumlah penduduk miskin. Selain itu, sebagian peneliti di atas menggunakan data time series dan yang lainnya menggunakan data primer (hasil survei) yang kemudian dianalisis menggunakan statistik deskriptif dan regresi linier sehingga temuan yang mereka peroleh lebih didasarkan pada "historical data" dan "cross sectional data" secara parsial.

Berbeda dengan peneliti sebelumnya, penelitian ini menggunakan data panel 15 kabupaten kota di Aceh dengan menempatkan DOK tidak hanya sebagai predictor variable bagi kemiskinan, tetapi juga sebagai moderating variable bagi hubungan fungsional antara zakat dan kemiskinan. Model analisis ekonometrika yang digunakan untuk menganalisis hubungan sebab akibat antar variabel tidak hanya terbatas pada regresi panel, tetapi juga moderated regression analysis (MRA). Sehingga temuan penelitian dapat mengungkapkan sejauhmana keberadaan DOK memoderasi pengaruh zakat terhadap penurunan kemiskinan.

\subsection{Keterkaitan antara Zakat dengan Kemiskinan}

Eksistensi zakat dalam meningkatkan taraf hidup masyarakat miskin menjadi bagian penting dari ajaran Islam (Johari et al., 2014). Membayar zakat adalah kewajiban bagi setiap muslim yang sudah memenuhi syarat wajib zakat (muzakki). Mereka berkewajiban membayarkan zakat kepada mustahiq zakat yang diantaranya adalah mereka yang hidup dalam kemiskinan. Sehingga terdapat aliran pendapatan dari kelompok masyarakat yang hidup diluar kemiskinan ke kelompok miskin sebagai penerima zakat (mustahiq).

Kajian mengenai dampak zakat terhadap kemiskinan telah menjadi perhatian banyak peneliti. Sebagian di antara mereka membuktikan signifikansi dan eksistensi dana zakat dalam menurunkan tingkat kemiskinan (Abdelbaki, 2013; Aisyah, 2014; Murniati \& Meik, 2015). Penelitian Mohamed et al. (2019) di Selangor Malaysia, memperkuat bukti empiris bahwa dana zakat berdampak signifikan pada penurunan kemiskinan. Di sisi lain terdapat hasil kajian empiris yang menyimpulkan bahwa zakat memiliki kontribusi relatif kecil terhadap penurunan kemiskinan (Ali et al., 2015). Kendatipun zakat dapat meningkatkan pendapatan dan memperbaiki kondisi ekonomi penerima zakat, tetapi tidak secara signifikan berdampak pada pengurangan jumlah penduduk miskin (Hoque et al., 2015; Redha et al., 2016).

Berbeda dengan kesimpulan peneliti di atas, sejumlah peneliti menemukan bahwa dana zakat tidak mampu memperbaiki kesejahteraan kelompok miskin. Indek kemiskinan masyarakat tidak mengalami perubahan antara kondisi sebelum dan setelah menerima zakat (Mubarokah et al., 2017). Penyaluran dana zakat kepada kelompok miskin tidak mampu mengurangi jumlah penduduk miskin secara aggregate (Nurjanah et al., 2019). Secara umum zakat belum berdampak signifikan terhadap perbaikan kesejahteraan masyarakat (Khasandy \& Badrudin, 2019). Hal ini berarti bahwa kesejahteraan kelompok miskin sebelum dan setelah menerima zakat tidak memiliki perubahan.

Temuan sejumlah peneliti di atas secara eksplisit menginformasikan bahwa dampak zakat terhadap penurunan kemiskinan masih perlu menjadi perdebatan. Kendatipun pendistribusian dana zakat kepada kelompok miskin dapat meningkatkan pendapatan dan memperbaiki konsumsi mereka, namun penggunaan dana zakat tersebut belum sepenuhnya mampu menyelesaikan persoalan kemiskinan secara umum. 


\subsection{Keterkaitan antara Dana Otonomi Khusus Dengan Kemiskinan}

Adanya DOK bagi daerah dengan status otonomi khusus seperti halnya Aceh diharapkan dapat berdampak pada kesejahteraan masyarakat di daerah tersebut. DOK merupakan transfer pemerintah pusat ke daerah dalam bentuk dana desentralisasi yang bersifat unconditional nonmatching grant atau block grants (Zulham et al., 2015). DOK bagi Aceh berawal dari UU No. 18 tahun 2001 tentang Otonomi Khusus bagi Daerah Istimewa Aceh menjadi Nanggroe Aceh Darussalam. Kemudian dalam UU No. 11 tahun 2006 tentang Pemerintah Aceh dinyatakan bahwa DOK merupakan salah satu pendapatan Aceh yang digunakan untuk membiayai pembangunan dan pemeliharaan infrastruktur, pemberdayaan ekonomi masyarakat, pengentasan kemiskinan serta pendanaan pendidikan, sosial dan kesehatan. Infrastruktur yang dimaksudkan di antaranya berupa infrastruktur transportasi seperti jalan dan jembatan, infrastruktur pendukung bagi kegiatan ekonomi di sektor pertanian seperti waduk dan irigasi misalnya dan belanja barang modal yang semuanya bertujuan untuk meningkatkan perekomian di daerah (Amri, 2017b). Semakin baik infrastruktur tersebut semakin lancar kegiatan ekonomi masyarakat yang pada gilirannya dapat meningkatkan pendapatan mereka (Amri, 2014). Pemanfaatan DOK oleh pemerintah Aceh tidak hanya berorientasi pada peningkatan pertumbuhan ekonomi di daerah, tetapi juga berorientasi pada penurunan tingkat kemiskinan.

Kajian mengenai keterkaitan antara DOK dengan pembangunan ekonomi dan penurunan tingkat kemiskinan telah dilakukan oleh sejumlah peneliti. Faradisi (2015) menemukan bahwa DOK berdampak positif terhadap pertumbuhan ekonomi. Penelitian Arie et al. (2017) tentang pengelolaan DOK di Papua menemukan bahwa keberadaan dana tersebut belum memberikan dampak yang signifikan bagi peningkatan kesejahteraan masyarakat secara umum. Hal ini disebabkan manajemen pengelolaan dana tersebut belum berjalan secara efektif.

\subsection{Peran Dana Otonomi Khusus dalam Hubungan Antara Zakat dan Kemiskinan}

Sebagaimana dijelaskan sebelumnya, dana zakat merupakan hak bagi kelompok miskin sebagai salah satu kelompok mustahiq zakat. Pemberian dana zakat diharapkan mampu memperbaiki taraf mereka. Adanya dampak zakat terhadap penurunan tingkat kemiskinan telah dibuktikan oleh sejumlah peneliti (Ayuniyyah et al., 2018). Kendatipun sebagian di antara mereka menyimpulkan bahwa dana zakat tidak berdampak signifikan terhadap penurunan kemiskinan, namun penyaluran zakat berarti adanya pendistribusian pendapatan dari wajib zakat (muzakki) kepada mereka yang hidup dalam kemiskinan, sehingga zakat dapat meningkatkan pendapatan mereka.

Upaya penurunan tingkat kemiskinan dan peningkatan kesejahteraan masyarakat juga dilakukan oleh pemerintah daerah melalui kebijakan anggaran belanja daerah (Amri \& Aimon, 2017). Anggaran daerah merupakan instrumen kebijakan fiskal daerah yang penggunaannya untuk membiayai program dan kegiatan pembangunan dimaksudkan untuk mendukung aktivitas ekonomi di daerah seperti pembangunan irigasi, jalan, jembatan dan infrastruktur fisik lainnya guna mendukung kegiatan ekonomi masyarakat dan memperluas kesempatan kerja (Muliadi \& Amri, 2019) serta mengurangi tingkat pengangguran dan meningkatkan partisipasi angkatan kerja di daerah (Amri, 2018). Bagi daerah dengan status otonomi khusus seperti halnya Aceh, sebagian dana pembangunan di tersebut bersumber dari dana otonomi khusus (DOK). Hal ini mengindikasikan bahwa pemanfaatan dana tersebut dalam mendukung kegiatan pembangunan di Aceh juga dimaksudkan untuk meningkatkan kesejahteraan masyarakat dan menurunkan tingkat kemiskinan. Mengingat keberadaan dana zakat juga diharapkan dapat menurunkan kemiskinan, maka DOK dapat ditempatkan sebagai moderating variable bagi hubungan kausalitas antara kedua variabel tersebut. Jika dampak dana zakat terhadap 
kemiskinan terjadi secara langsung melalui perpindahan pendapatan dari muzakki ke mustahiq zakat, dampak DOK terhadap kemiskinan justru terjadi secara tidak langsung melalui alokasi anggaran belanja daerah untuk membiayai pembangunan dan pemeliharaan infrastruktur, pemberdayaan ekonomi masyarakat, dan pendanaan pendidikan dan kesehatan. Sehingga zakat sebagai "instrumen ajaran islam" dan DOK sebagai "instrumen kebijakan fiskal daerah" saling berinteraksi dalam menurunkan kemiskinan.

\section{Metode Penelitian}

Data yang digunakan dalam penelitian ini adalah data sekunder yang bersumber dari instansi terkait seperti Baitul Mal Aceh dan Badan Pusat Statistik. Data tersebut berbentuk panel data terdiri dari data time series (runut waktu) selama periode tahun 2010-2016 ( $\mathrm{n}=7$ ) dan data kerat silang (cross section data) yang diambil dari 15 kabupaten kota di Aceh terdiri dari Aceh Selatan, Aceh Tenggara, Aceh Singkil, Aceh Timur, Aceh Tengah, Langsa, Aceh Barat, Pidie, Aceh Utara, Lhokseumawe, Bireun, Sabang, Simeulue, Pidie Jaya dan Subulussalam. Pemilihan daerah tersebut sebagai sampel didasarkan pada sejumlah alasan: (1) penerimaan zakat per kapita relatif lebih besar dibandingkan dengan daerah lainnya di Aceh, dan (2) penerimaan DOK per kapita serta tingkat kemiskinan di daerah tersebut juga relatif lebih tinggi dibandingkan daerah lainnya.

Variabel yang dioperasionalkan dalam penelitian ini terdiri dari penerimaan zakat, DOK dan kemiskinan. Penerimaan zakat diproksi dari realiasi penerimaan zakat per kapita yang dihitung dengan satuan ribu rupiah per kapita. DOK adalah realisasi penerimaan daerah yang bersumber dari DOK Aceh yang kemudian digunakan untuk membiayai program pembangunan dan pemiliharaan infrastruktur, pemberdayaan ekonomi masyarakat, pengentasan kemiskinan, program pendidikan dan kesehatan. Variabel ini juga diukur dengan satuan ribu rupiah per kapita. Selanjutnya kemiskinan diproksi dari jumlah penduduk miskin diukur dengan satuan jiwa.

Guna menganalisis pengaruh penerimaan zakat dan DOK terhadap kemiskinan, model ekonometrika yang digunakan adalah regresi panel. Penggunaan model tersebut didasarkan pada alasan bahwa estimasi mengenai hubungan fungsional antar variabel pada dasarnya menggunakan data panel seperti dijelaskan di atas. Secara ekonometrik model regresi panel yang menjelaskan hubungan fungsional antara kemiskinan dengan zakat dan DOK diformulasikan dalam persamaan 1 .

$\mathrm{MSK}_{\mathrm{it}}=\beta_{0}+\beta_{1} \mathrm{ZKT}_{\mathrm{it}}+\beta_{2} \mathrm{DOK}_{\mathrm{it}}+e_{\mathrm{it}}$

Dimana

$\beta_{0} \quad$ : Konstanta

MSK $_{\text {it }}$ : Kemiskinan di kabupaten/kota i pada tahun $\mathrm{t}$

$\mathrm{ZKT}_{\text {it }}$ : Realisasi penyaluran zakat di kabupaten/kota i pada tahun $\mathrm{t}$

DOK $_{\text {it }}$ : Relisasi dana otonomi khusus di kabupaten/kota i pada tahun $\mathrm{t}$

$\beta_{1}$ dan $\beta_{2}$ : Koefisien regresi $\mathrm{ZKT}_{\mathrm{it}}$ dan $\mathrm{DOK}_{\mathrm{it}}$

i $\quad:$ Kabupaten/kota $(1,2, \ldots, 15)$

$\mathrm{t} \quad:$ Tahun $(2010,2012 \ldots, 2016)$

e : Error term

Mengingat masing-masing variabel memiliki ukuran berbeda, diperlukan adanya proses transformasi data dalam bentuk logaritma, sehingga persamaan 1 tersebut dimodifikasi menjadi persamaan 2 .

$\mathrm{LMSK}_{\mathrm{it}}=\beta_{0}+\beta_{1} \mathrm{LZKT}_{\mathrm{it}}+\beta_{2} \mathrm{LDOK}_{\mathrm{it}}+e_{\mathrm{it}}$

Dimana

$\beta_{0} \quad$ : Konstanta

LMSK $_{\text {it }}$ : Logaritma kemiskinan di kabupaten/ kota i pada periode $\mathrm{t}$

LZKT $_{\text {it }}$ : Logaritma realisasi belanja modal di kabupaten/kota i pada periode $\mathrm{t}$

$\mathrm{LDOK}_{\text {it }}$ : Logaritma realisasi DOK di kabupaten/ kota i pada periode $\mathrm{t}$

$\beta_{1}$ dan $\beta_{2}$ : Koefisien regresi $L Z K T_{\text {it }}$ dan $L_{D O K}$

i : Kabupaten/kota $(1,2, \ldots, 15)$

$\mathrm{t} \quad:$ Tahun $(2010,2012 \ldots, 2016)$

e : Errorterm 
Sebagaimana dijelaskan sebelumnya, kajian ini juga menempatkan DOK sebagai variabel pemoderasi antara penerimaan zakat dan kemiskinan. Keberadaan moderating variable dalam hubungan sebab akibat antara dua variabel atau lebih berimplikasi bahwa model analisis yang digunakan adalah moderated regression analysis (MRA). MRA dapat menganalisis pengaruh moderating variable dalam suatu model regresi (Ghozali, 2011). Sehingga persamaan 2 dimodifikasi menjadi MRA seperti ditunjukkan dalam persamaan 3.

$\mathrm{LMSK}_{\mathrm{it}}=\beta_{0}+\beta_{1} \mathrm{LZKT}_{\mathrm{it}}+\beta_{2} \mathrm{LDOK}_{\mathrm{it}}+\beta_{3} \mathrm{MDR}_{\mathrm{it}}+e_{\mathrm{it}}(3)$

Dimana

$\beta_{0} \quad$ : Konstanta

LMSK $_{\text {it }}$ : Logaritma

kemiskinan

di

kabupaten/kota i pada periode $\mathrm{t}$

LZKT $_{\text {it }}$ : Logaritma realisasi belanja modal di kabupaten/kota i pada periode $t$

$\mathrm{LDOK}_{\text {it }}$ : Logaritma realisasi DOK kabupaten/ kota i pada periode $\mathrm{t}$

MDR $_{i t}$ : Perkalian antara LZKT ${ }_{i t}$ dan $\mathrm{LDOK}_{\text {it }}$

$\beta_{1}, \beta_{2,} \beta_{3}$ : Koefisien regresi $\mathrm{LZKT}_{\text {it }}, \mathrm{LDOK}_{\mathrm{it}}$ dan $\mathrm{MDR}_{\text {it }}$

i : Kabupaten/kota $(1,2, \ldots, 15)$

$\mathrm{t} \quad$ : Tahun $(2010,2012 \ldots, 2016)$

e : Error term

Regresi panel memiliki tiga pendekatan yaitu common effect model, fixed effect model dan random effect model. Pemilihan mana di antara tiga pendekatan tersebut yang dapat menghasilkan estimasi terbaik digunakan Chow test dan Hausman test. Chow test menentukan pilihan model terbaik antara common effect atau fixed effect model. Selanjutnya Hausman test menentukan pilihan terbaik antara fixed effect atau random effect model (Muliadi \& Amri, 2019).

Penentuan signifikansi pengaruh salah satu predictor variable (penerimaan zakat atau DOK) secara parsial terhadap tkemiskinan didasarkan pada nilai $p$-value yang dihasilkan oleh proses pengolahan data menggunakan software E-Views, dengan ketentuan jika suatu variabel memiliki nilai $p$-value $<0,05$ berarti variabel tersebut berpengaruh signifikan. Sebaliknya jika memiliki nilai $p$-value $>0,05$ berarti tidak berpengaruh signifikan.

Selanjutnya pengujian efek moderasi DOK dalam hubungan antara penerimaan zakat dan kemiskinan didasarkan pada signifikansi nilai koefisien estimasi $\operatorname{LDOK}_{\mathrm{it}}\left(\beta_{2}\right)$ dan variabel pemoderasi $\left(\mathrm{MDR}_{\mathrm{it}}\right)\left(\beta_{3}\right)$ dengan ketentuan jika $\beta_{2}$ tidak signifikan ( $p$-value $\left.>0,05\right)$ dan $\beta_{3}$ signifikan ( $p$-value $<0,05)$, variabel DOK dikatakan memiliki efek moderasi murni. Sementara itu, jika $\beta_{2}$ dan $\beta_{3}$ keduanya adalah signifikan ( $p$-value $<0,05)$, variabel DOK dikatakan memiliki efek quasi moderasi. Selanjutnya, jika $\beta_{2}$ signifikan ( $p$-value $<0,05$ ), dan $\beta_{3}$ tidak signifikan ( $p$-value $>0,05$ ), variabel DOK hanya dianggap sebagai variabel independen dan tidak berperan sebagai variabel moderasi.

\section{Hasil dan Pembahasan}

\subsection{Hasil Penelitian}

Jumlah penduduk miskin pada masingmasing daerah di Aceh relatif berbeda antara daerah yang satu dengan daerah lainnya. Perbedaan tersebut tidak hanya terjadi antar kupaten kota, tetapi pada daerah yang sama pada periode tahun berbeda. Hingga tahun 2016, daerah dengan kemiskinan tertinggi adalah kabupaten Aceh Utara dengan penduduk miskin sebesar 115.050 jiwa. Kemudian menyusul kabupaten Pidie di urutan kedua dengan penduduk miskin sebesar 90.160 jiwa. Pada tahun yang sama, daerah dengan kemiskinan terendah adalah kota Sabang sebanyak 5.810 jiwa.

Realisasi penerimaan zakat di masingmasing daerah juga relatif berbeda. Demikian pula halnya dengan realisasi Dana Otonomi Khusus (DOK) juga berbeda antara daerah yang satu dengan daerah lainnya. Pada tahun 2016 daerah dengan penerimaan zakat paling tinggi adalah kota Sabang sebesar Rp96.525,- per kapita. Kemudian menyusul kabupaten Aceh Tengah di urutan kedua dengan penerimaan zakat per kapita sebesar Rp83.461.,-. Sebaliknya daerah dengan penerimaan zakat paling rendah 
adalah kabupaten Pidie yakni sebesar Rp761 per kapita.

Dalam periode tahun yang sama, daerah dengan DOK paling besar adalah kota Subulussalam sebesar Rp1,371.412 per kapita, kemudian kabupaten Simeulue di urutan kedua sebesar Rp1,179.281 per ka pita. Sebaliknya daerah dengan DOK paling kecil adalah kabupaten Aceh Utara sebesar Rp218.241 per kapita.Untuk lebih jelasnya mengenai Hasil kemiskinan, penerimaan zakat dan DOK seperti ditunjukkan dalam Tabel 1.

Tabel 1.Hasil Statistik Deskriptif Variabel Penelitian

\begin{tabular}{|llll}
\hline & $\begin{array}{c}\text { Kemiskina } \\
\text { (000Jiwa) }\end{array}$ & $\begin{array}{c}\text { Penerimaan } \\
\text { Zakat (Rp000 } \\
\text { per Kapita) }\end{array}$ & $\begin{array}{c}\text { DOK } \\
\text { (Rp000 } \\
\text { per kapita) }\end{array}$ \\
\hline Mean & 41,278 & 21,957 & 744,858 \\
Maximum & 124,660 & 96,520 & $2.139,010$ \\
Minimum & 5,590 & 0,760 & 218,240 \\
Std. Dev. & 30,336 & 22,053 & 434,208 \\
\hline
\end{tabular}

Sumber: Data Sekunder (Diolah), 2019.

Tabel 1 memperlihatkan parameter statistik deskriptif masing-masing variabel. Nilai rata-rata (mean) kemiskinan sebesar 41.278 jiwa. Selanjutnya nilai mean penerimaan zakat dan DOK per kapita masing-masing sebesar Rp21.957,- dan Rp744.858,-. Nilai mean yang dimaksudkan bukan hanya nilai rata-rata kabupaten kota, tetapi nilai rata-rata data panel pada setiap variabel.

\subsection{Pembahasan}

Sebagaimana dijelaskan sebelumnya, model analisis yang digunakan untuk menganalisis pengaruh penerimaan zakat dan DOK terhadap kemiskinan adalah regresi panel (persamaan 2). Selanjutnya analisis efek moderasi DOK terhadap hubungan kausalitas antara zakat dan penurunan kemiskinan menggunakan Moderated Regression Analysis (MRA) (persamaan 3). Kedua model ekonometrika tersebut terdiri dari tiga pendekatan yakni common effect, fixed effect dan random effect. Pemilihan model terbaik di antara tiga pendekatan tersebut menggunakan Chow test dan Hausman test. Chow test menentukan apakah model yang dipilih common effect atau fixed effect, didasarkan pada nilai $p$ value untuk cross-section $F$ dengan ketentuan jika $p$-value $>0,05$ maka model adalah common effect. Sebaliknya jika $p$-value $<0,05$ maka model yang dipilih adalah fixed effect. Hasil Chow test untuk regresi panel dan MRA seperti ditunjukkan dalam Tabel 2.

Tabel 2. Hasil Chow Test Regresi Panel dan MRA

\begin{tabular}{|c|c|c|c|c|}
\hline \multicolumn{5}{|c|}{ Hasil Chow Test Regresi Panel } \\
\hline $\begin{array}{c}\text { Uji } \\
\text { Efek }\end{array}$ & & Statistic & df & $\begin{array}{c}p- \\
\text { value }\end{array}$ \\
\hline $\begin{array}{l}\text { Cross- } \\
\text { Section }\end{array}$ & $\begin{array}{l}\text { Cross- } \\
\text { section }\end{array}$ & 476,732 & $(14,88)$ & 0,000 \\
\hline $\begin{array}{l}\text { Fixed } \\
\text { Effects }\end{array}$ & $\begin{array}{l}\mathrm{F} \\
\text { Cross- } \\
\text { section } \\
\mathrm{X} 2\end{array}$ & 455,886 & 14 & 0,000 \\
\hline \multicolumn{5}{|c|}{ Hasil Chow Test MRA } \\
\hline $\begin{array}{c}\text { Uji } \\
\text { Efek }\end{array}$ & & Statistic & $\mathrm{df}$ & $\begin{array}{c}p- \\
\text { value }\end{array}$ \\
\hline $\begin{array}{l}\text { Cross- } \\
\text { Section }\end{array}$ & $\begin{array}{l}\text { Cross- } \\
\text { section }\end{array}$ & 487,482 & $(14,87)$ & 0,000 \\
\hline $\begin{array}{l}\text { Fixed } \\
\text { Effects }\end{array}$ & $\begin{array}{l}\mathrm{F} \\
\text { Cross- } \\
\text { section } \\
\mathrm{X}^{2}\end{array}$ & 459,382 & 14 & 0,000 \\
\hline
\end{tabular}

Sumber: Data Sekunder (Diolah), 2019.

Tabel 2 memperlihatkan nilai $p$-value cross section $\mathrm{F}$ sebesar $0,000(<0,05)$, baik untuk regresi panel maupun MRA. Dengan demikian dapat disimpulkan bahwa berdasarkan Chow test, model yang dipilih adalah fixed effect model.

Selanjutnya Haussman test digunakan untuk menentukan apakah model yang dipilih fixed effect atau random effect. Pemilihan salah satu di antara kedua model tersebut didasarkan pada nilai p-value cross-section random dengan ketentuan jika nilai $p$-value $>0,05$ maka model yang dipilih adalah random effect. Sebaliknya jika nilai $p$-value $<0,05$ maka model yang dipilih adalah fixed effect. Hasil uji Haussman test untuk regresi panel dan MRA seperti ditunjukkan dalam Tabel 3. 
Jurnal Ilmiah Ekonomi Islam, 5(03), 2019, 238

Tabel 3. Hasil Haussman Test Regresi Panel dan MRA

\begin{tabular}{|c|c|c|c|}
\hline \multicolumn{4}{|c|}{ Hasil Haussman Test Regresi Panel } \\
\hline Uji Efek & $\mathrm{X}^{2}$-Statistic & df & $p$-value \\
\hline $\begin{array}{l}\text { Cross-Section } \\
\text { Random Effects }\end{array}$ & 26,491 & 2 & 0,000 \\
\hline \multicolumn{4}{|c|}{ Hasil Haussman Test MRA } \\
\hline Uji Efek & $\mathrm{X}^{2}$-Statistic & df & $p$-value \\
\hline $\begin{array}{l}\text { Cross-Section } \\
\text { Random Effects }\end{array}$ & 24,848 & 3 & 0,000 \\
\hline
\end{tabular}

Sumber: Data Sekunder (Diolah), 2019.

Tabel 3 memperlihatkan nilai nilai $p$-value haussman test baik untuk regresi panel maupun MRA sebesar sebesar 0,000. Sehingga dapat disimpulkan bahwa fixed effect model lebih baik bila dibandingkan dengan random effect model. Sebelumnya hasil Chow test (tabel 2) juga mengindikasikan bahwa model terbaik juga fixed effect model. Justifikasi statistik yang mengindikasikan bahwa fixed effect model memiliki hasil estimasi lebih akurat dibandingkan dengan random effect model juga dapat didasarkan pada perbandingan grafik residual yang dihasilkan oleh kedua pendekatan tersebut seperti ditunjukkan dalam Grafik 1 dan 2 .

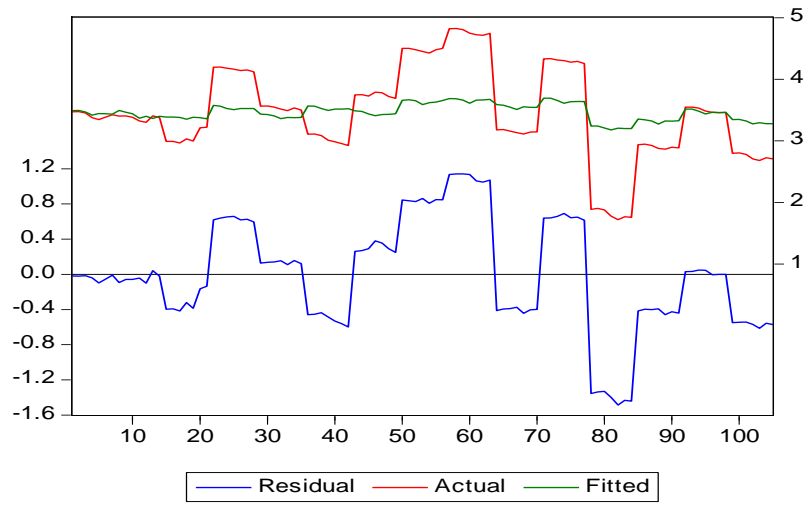

Grafik 1a Residual Metode Random Effect Model Regresi Panel

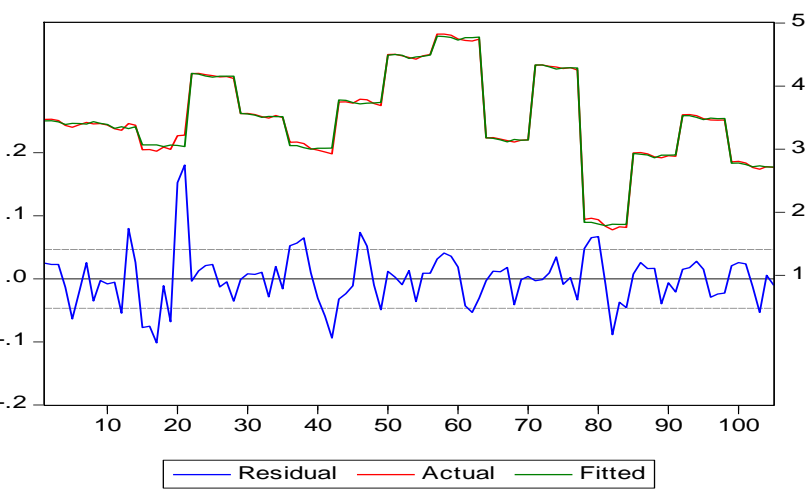

Grafik 1b Residual Metode Fixed Effect Model Regresi Panel

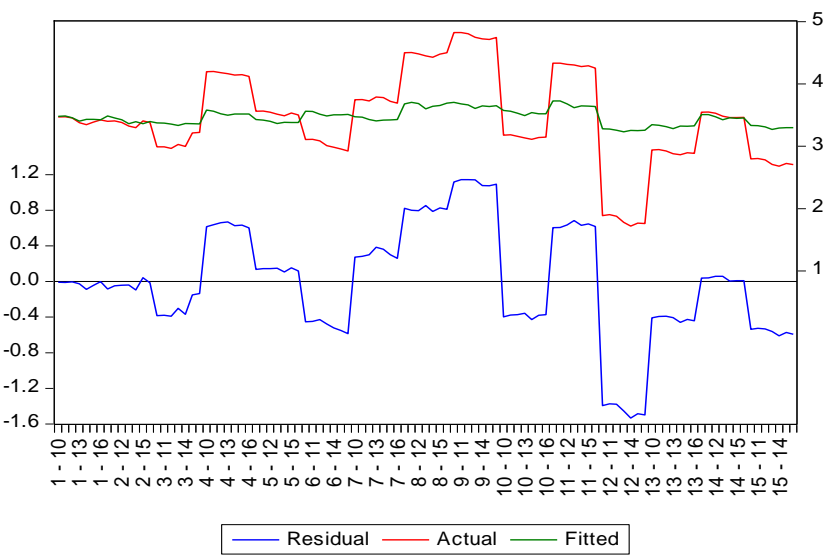

Grafik 2a Residual Metode Random Effect Model $M R A$

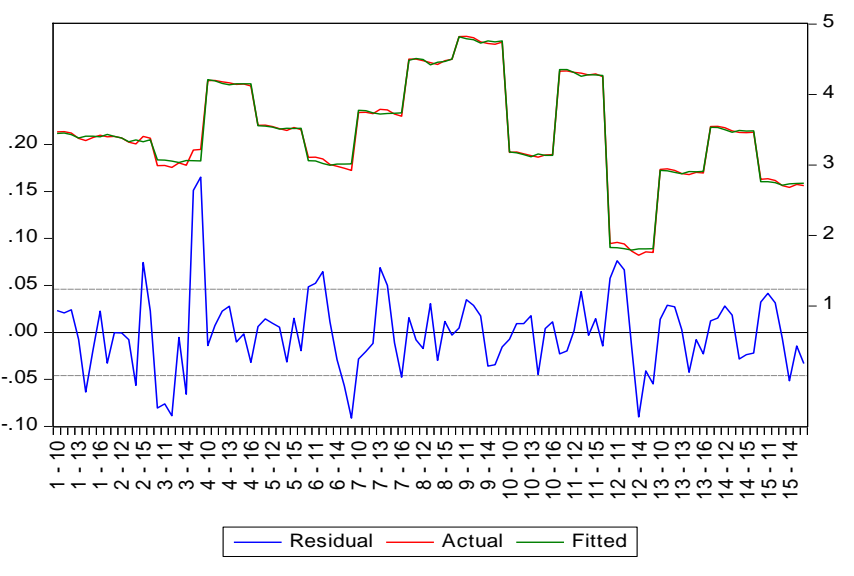

Grafik 2b Residual Metode Fixed Effect Model $M R A$

Grafik 1a dan 2a menggambarkan residual regresi panel dan MRA yang dihasilkan dari pendekatan random effect model. Pada grafik tersebut terlihat bahwa variasi/fluktuasi garis actual cenderung berbeda dengan fluktuasi garis fitted. Selanjutnya Grafik $1 \mathrm{~b}$ dan $2 \mathrm{~b}$ memperlihatkan residual regresi panel dan MRA yang dihasilkan oleh pendekatan fixed effect model. Pada grafik tersebut terlihat bahwa 
variasi/fluktuasi garis actual hampir sama dengan fluktuasi garis fitted. Berdasarkan perbandingkan garis actual dan garis fitted pada kedua grafik tersebut juga dapat disimpulkan bahwa pendekatan fixed effect model menghasilkan estimasi yang lebih akurat bila dibandingkan dengan pendekatan random effect model. Karena itu, regresi panel dan MRA yang dipilih dan kemudian digunakan untuk kepentingan analisis dalam penelitian ini adalah fixed effect model.

Ketepatan estimasi dengan menggunakan regresi sebagai alat analisis data tidak terlepas dari adanya asumsi klasik terutama asumsi non multikolinieritas.Uji multikolinieritas dalam hal ini dilakukan dengan membandingkan nilai Adjusted $R^{2}$ hasil regresi panel dan MRA dengan nilai koefisien korelasi ( $r$ ) antara sesama predictor variable. Dalam model regresi panel, predictor variable terdiri dari zakat $\left(\mathrm{LZKT}_{\mathrm{it}}\right)$ dan dana otonomi khusus $\left(\mathrm{LDOK}_{\mathrm{it}}\right)$. Selanjutnya dalam MRA menambahkan variabel moderasi $\left(\mathrm{MDR}_{\mathrm{it}}\right)$ sebagai predictor variable ketiga selain dua variabel tersebut. Koefisien korelasi antar ketiga variabel seperti ditunjukkan dalam Tabel 4.

Tabel 4. Koefisien Korelasi antar Variabel dan Adjusted- $\mathbf{R}^{2}$ Regresi Panel dan MRA

\begin{tabular}{lllll}
\hline & LMSK $_{\text {it }}$ & LZKT $_{\text {it }}$ & LDOK $_{\text {it }}$ & MDR $_{\text {it }}$ \\
\hline LMSK $_{\text {it }}$ & 1,000 & & & \\
LZKT $_{\text {it }}$ & $-0,605$ & 1,000 & & \\
LDOK $_{\text {it }}$ & $-0,841$ & 0,536 & 1,000 & \\
MDR $_{\text {it }}$ & $-0,705$ & 0,981 & 0,678 & 1,000
\end{tabular}

Koefisien Determinasi (Adjusted- $\mathbf{R}^{2}$ )

Hasil Regresi Panel : : 0,9959

Hasil MRA : : 0,9659

Sumber: Data Sekunder (Diolah), 2019.

Tabel 4 menunjukkan koefisien korelasi (r) antara penerimaan zakat $\left(\mathrm{LZKT}_{\mathrm{it}}\right)$ dan dana Otsus $\left(\mathrm{LDOK}_{\mathrm{it}}\right)$ sebesar 0,536. Selanjutnya koefisien korelasi antara moderating variable $\left(\mathrm{MDR}_{\mathrm{it}}\right)$ dengan penerimaan zakat dan dana Otsus masing-masing sebesar 0.981 dan 0.678. Angka ini lebih kecil dari nilai Adjusted- $R^{2}$ hasil regresi panel dan MRA sebesar 0,9959. Hal ini berarti bahwa model regresi panel dan MRA yang digunakan untuk memprediksi kemiskinan di Aceh terbebas dari gejala multikolinieritas.

\section{Analisis Pengaruh Zakat dan Dana Otonomi} Khusus terhadap Tingkat Kemiskinan

Penerimaan zakat dan DOK berpengaruh negatif dan signifikan terhadap kemiskinan di Aceh, ditunjukkan koefisien estimasi masingmasing variabel bernilai negatif dan p-value< 0,05 . Hal ini dapat dilihat dari hasilregresi panel seperti ditunjukkan dalam Tabel 5.

Tabel 5. Hasil Regresi Panel

Dependent Variable: LMSK $_{\text {it }}$ (kemiskinan)

Method: Panel Least Squares

Variabl

e Coefficient Std. Error t-Statistic P-Value

$\begin{array}{lllll}\mathrm{C} & 4,562 & 0,269 & 16,950 & 0,000\end{array}$

LZKT $_{\text {it }}-0,023 \quad 0,012 \quad-2,013 \quad 0,047$

LDOK $_{\text {it }}-0,160 \quad 0,043 \quad-3,766 \quad 0,000$

$\mathrm{R}^{2}=0,997 ;$ Adjusted- $\mathrm{R}^{2}=0,996 ;$ F-statistic $=$ 1618,103; Prob(F-test) $=0,000 ;$ Durbin-Watson test $=1,023$

Sumber: Data Sekunder (Diolah), 2019.

Berdasarkan Tabel 5 di atas, regresi panel yang menjelaskan pengaruh penerimaan zakat dan DOK terhadap kemiskinan dapat dinyatakan dalam persamaan 4 .

$\mathrm{LMSK}_{\mathrm{it}}=4,562-0,023 \mathrm{LZKT}_{\mathrm{it}}-0,160 \mathrm{LDOK}_{\mathrm{it}}$ (4)

Secara skematis pengaruh zakat dan DOK terhadap kemiskinan seperti ditunjukkan dalam Gambar 3.

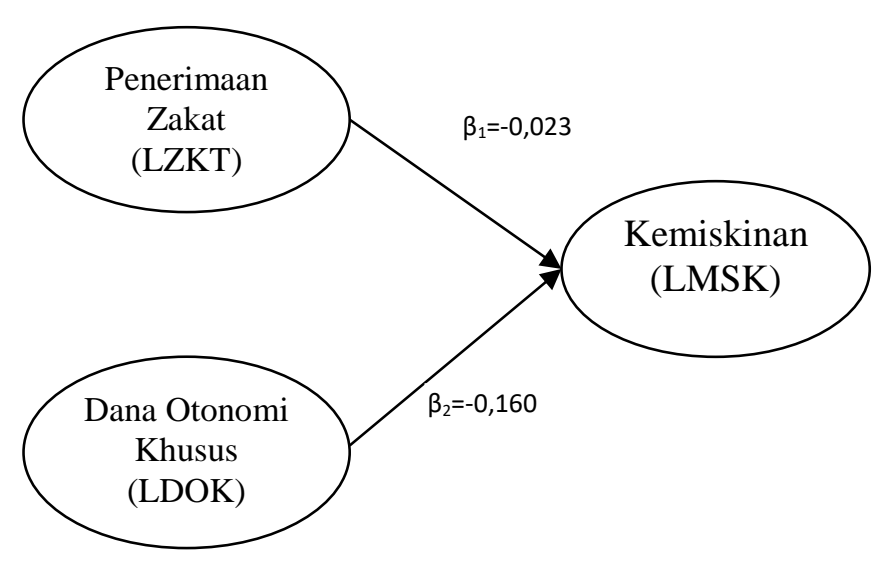

Gambar 3

Skema Pengaruh Zakat dan DOK terhadap Kemiskinan 
Penerimaan zakat berpengaruh negatif dan signifikan terhadap tingkat kemiskinan di Aceh. Hal ini ditunjukkan oleh koefisien estimasi sebesar -0,023 ( $p$-value $=0,047<0,05)$. Secara statistik, angka tersebut dapat diinterpretasikan bahwa setiap peningkatan penerimaan zakat per kapita sebesar $1 \%$ dapat menurunkan jumlah penduduk kemiskinan sebesar $0,023 \%$ dengan asumsi realisasi DOK tidak mengalami perubahan. Adanya dampak negatif dan signifikan zakat terhadap kemiskinan disebabkan zakat yang dikumpulkan oleh Baitul Mal sebagai lembaga pengelola zakat di Aceh secara langsung disalurkan kepada mustahiq zakat yang umumnya mereka adalah kelompok fakir dan miskin. Sehingga peningkatan penerimaan zakat berarti terjadinya peningkatan dana zakat yang disalurkan kepada kelompok miskin. Dana zakat tersebut tidak hanya disalurkan dalam bentuk uang guna memenuhi kebutuhan konsumsi mustahiq (zakat konsumtif), tetapi sebagian juga dalam bentuk modal kerja dan alat-alat produksi untuk mendukung kegiatan ekonomi produktif (zakat produktif) bagi mustahiq yang telah memiliki usaha.

Hasil penelitian ini konsisten dengan hasil kajian Abdelbaki (2013) tentang keterkaitan antara zakat dan kemiskinan di sejumlah negara Muslim dan temuan empiris Redha et al. (2016) di Algeria yang menyimpulkan bahwa pemanfaatan dana zakat dapat mengurangi tingkat kemiskinan. Temuan ini juga mendukung hasil penelitian sebelumnya yang dilakukan Johari et al. (2014) di Selangor Malaysia dan Ayuniyyah et al. (2018) di Jawa Barat yang juga menyimpulkan bahwa penyaluran zakat secara signifikan mampu menurunkan tingkat kemiskinan. Sebaliknya, hasil penelitian ini berbeda dengan temuan penelitian Isiaka et al. (2015) di Nigeria yang menyajikan bukti empiris bahwa dana zakat tidak secara signifikan dapat mengurangi kemiskinan di negara tersebut. Temuan penelitian ini juga bertolak belakang dengan hasil penelitian Khasandy \& Badrudin (2019) untuk kasus Indonesia juga mengindikasikan bahwa zakat belum mampu meningkatkan kesejahteraan masyarakat secara umum yang diindikasikan oleh turunnya indek pembangunan manusia dan semakin tingginya ketimpangan pendapatan di masyarakat.

Realisasi DOK juga berpenaruh negatif dan signifikan terhadap penurunan kemiskinan kabupaten kota di Aceh, ditunjukkan oleh kofisien estimasi sebesar -0,160 ( $p$-value $=0,000$ $<0,05)$. Peningkatan realisasi DOK per kapita sebesar $1 \%$ mendorong penurunan kemiskinan sebesar $0,160 \%$ dengan asumsi penerimaan zakat tidak berubah. Hal ini mengindikasikan bahwa keberadaan DOK Aceh yang diperuntukan untuk pembangunan dan pemeliharaan infrastruktur, membiaya kegiatan pemberdayaan ekonomi dan pengentasan kemiskinan di daerah tersebut telah mampu mengurangi jumlah penduduk miskin. Temuan ini berbeda dengan hasil kajian Fanggidae et al. (2016) dalam kasus Papua Barat yang menyimpulkan bahwa keberadaan DOK di daerah tersebut belum memberikan dampak signifikan terhadap penurunan tingkat kemiskinan.

\section{Peran DOK dalam Memoderasi Pengaruh Zakat terhadap Kemiskinan}

Menempatkan DOK sebagai moderating variable bagi pengaruh penerimaan zakat terhadap kemiskinan merupakan alasan yang sangat rasional ketika pengalokasian dana tersebut juga dimaksudkan untuk pembangunan infrastruktur dan pemberdayaan ekonomi masyarakat. Ketika zakat dilihat sebagai instrumen pengentasan kemiskinan yang bersumber dari ajaran Islam, maka DOK merupakan sebagai instrumen kebijakan fiskal pemerintah daerah yang tujuannya juga mengentaskan kemiskinan melalui sejumlah program pembangunan. Penelitian ini menemukan bahwa DOK tidak hanya menjadi predictor variable bagi penurunan tingkat kemiskinan di Aceh, tetapi juga memoderasi pengaruh zakat terhadap penurunan tingkat kemiskinan. Hasil MRA seperti ditunjukkan dalam Tabel 6. 
Tabel 6. Hasil Moderated Regression Analysis (MRA)

Dependent Variable: LMSK $_{\text {it }}$ (kemiskinan)

Method: Panel Least Squares

\section{Variabl}

e Coefficient Std. Error t-Statistic P-Value

$\begin{array}{lllll}\text { C } & 5,101 & 0,399 & 12,753 & 0,000\end{array}$

$\begin{array}{llll}\text { LZKT }_{\text {it }}-0,227 & 0,114 & -2,001 & 0,049\end{array}$

LDOK $_{\text {it }}-0,246 \quad 0,063 \quad-3,882 \quad 0,000$

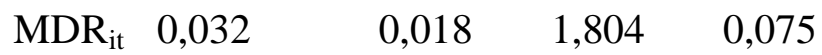

$\mathrm{R}^{2}=0,997 ;$ Adjusted- $\mathrm{R}^{2}=0,996 ;$ F-statistic $=$ 1.562,146; Prob(F-test) $=0,000 ;$ Durbin-Watson test $=1,052$

Sumber: Data Sekunder (Diolah), 2019.

Keterangan: $\quad p$-value $<0,10$ signifikan pada keyakinan 90\%; p-value $<0,05$ signifikan pada keyakinan 95\%; dan p-value $<0,01$ signifikan pada keyakinan $99 \%$.

Berdasarkan Tabel 5 maka MRA yang menempatkan DOK sebagai moderating variable terhadap hubungan fungsional antara penerimaan zakat dan kemiskinan seperti dinyatakan dalam persamaan 5.

$\mathrm{LMSK}_{\mathrm{it}}=5,101-0,227 \mathrm{LZKT}_{\mathrm{it}}-0,246 \mathrm{LDOK}_{\mathrm{it}}+$ $0,032 \mathrm{MDR}_{\text {it }}(5)$

Secara skematis penempatan DOK sebagai variabel pemoderasi dapat seperti dalam Gambar 4.

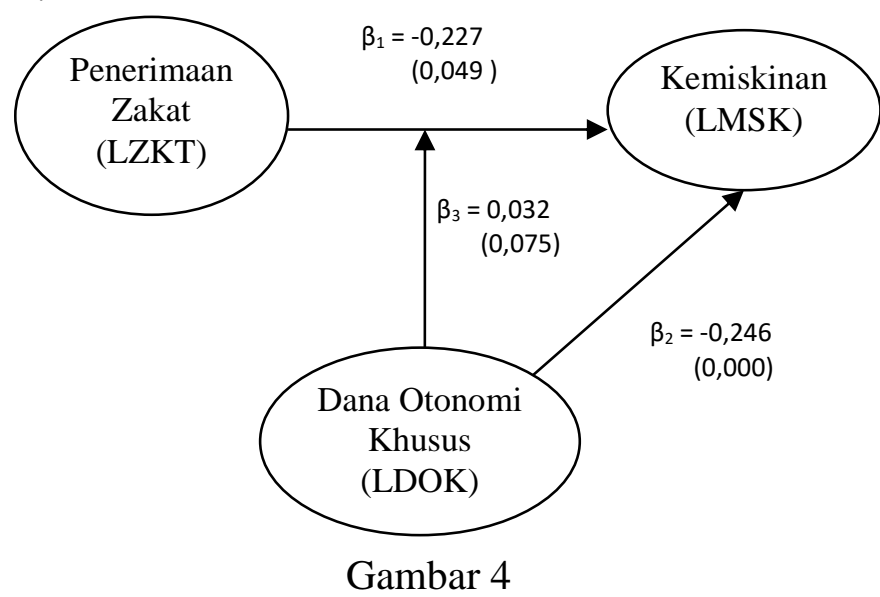

Skema Pengaruh DOK terhadap Hubungan antara Zakat dan Kemiskinan

Hasil MRA seperti dalam persamaan 5 di atas menunjukkan bahwa penerimaan zakat dan DOK juga berpengaruh negatif dan signifikan terhadap kemiskinan di Aceh, dengan koefisien estimasi masing-masing variabel sebesar -0,227 $(p$-value $=0,049)$, dan -0,246 $(p$-value $=0,000)$. Selanjutnya interaksi antara kedua predictor variable tersebut juga berpengaruh terhadap hubungan antara penerimaan zakat dan kemiskinan. Hal ini ditunjukkan oleh koefisien estimasi moderating variable $\left(\mathrm{MDR}_{\mathrm{it}}\right)$ sebesar $0,032(p$-value $=0,075)$, juga signifikan pada keyakinan $90 \%$. Hal ini mengindikasikan bahwa keberadaan DOK tidak hanya sebagai variabel independen (predictor variable), tetapi juga memoderasi pengaruh penerimaan zakat terhadap kemiskinan. Dengan kata lain, efek moderasi yang ditimbulkan oleh DOK dalam memoderasi pengaruh zakat terhadap kemiskinan adalah quasi moderasi.

Pengalokasian DOK untuk membiayai sejumlah program pemerintah kabupaten kota di Aceh sejalan upaya pemanfaatan dana zakat sebagai instrumen penurunan tingkat kemiskinan. Apalagi sesuai dengan petunjuk penggunaannya, DOK diperuntukan untuk pembangunan infrastruktur fisik dan pemberdayaan ekonomi masyarakat, sehingga berdampak terhadap kegiatan ekonomi di daerah yang kemudian meningkatkan pendapatan masyarakat. Peningkatan pendapatan pada gilirannya meningkatkan kemampuan muzakki untuk membayar zakat. Di sisi lain, perbaikan infrastruktur fisik juga memberikan dampak positif bagi kegiatan ekonomi kelompok miskin sehingga mereka dapat juga dapat bekerja lebih baik. Kendatipun dampak pengalokasian DOK terhadap kegiatan ekonomi masyarakat tidak terjadi secara langsung karena membutuhkan durasi waktu (lag time) tertentu, namun program yang didanai dengan dana tersebut tetap memberikan dampak positif terhadap kesejahteraan masyarakat dalam jangka panjang.

Seperti ditunjukkan dalam persamaan di atas, koefisien estimasi moderating variable $\left(\mathrm{MDR}_{\mathrm{it}}\right)$ bernilai positif. Hal ini berarti terdapat interaksi positif antara penerimaan zakat dan DOK dalam mempengaruhi kemiskinan di Aceh. Dengan kata lain, DOK memperbesar efek negatif penyaluran zakat terhadap kemiskinan. Secara statistik, peningkatan efek negatif tersebut dapat dilihat 
dari perbandingan koefisien estimasi penerimaan zakat terhadap kemiskinan antara sebelum dan setelah menempatkan DOK sebagai moderating variable.

Sebelum menempatkan DOK sebagai pemoderasi, koefisien estimasi zakat terhadap kemiskinan sebesar -0,023 persen (persamaan 4). Hal ini berarti bahwa setiap peningkatan $1 \%$ dana zakat mampu menurunkan kemiskinan sebesar $0,023 \%$. Selanjutnya menempatkan DOK sebagai variabel pemoderasi, koefisien estimasi tersebut meningkat menjadi sebesar $-0,227$ (persamaan 5) yang berarti peningkatan dana zakat sebesar $1 \%$ berdampak pada penurunan kemiskinan sebesar $0,227 \%$.

\section{Kesimpulan}

Penelitian ini bertujuan untuk menganalisis pengaruh penerimaan zakat terhadap penurunan tingkat kemiskinan di Aceh dengan menggunakan dana otonomi khusus (DOK) sebagai variabel pemoderasi. Menggunakan data panel 15 kabupaten kota di Aceh, regresi panel dan moderated regression analysis (MRA) digunakan sebagai model analisis data. Temuan penting yang dapat diperoleh adalah, penyaluran zakat dan DOK secara signifikan mampu menurunkan jumlah penduduk miskin. DOK sebagai instrumen kebijakan fiskal daerah memiliki pengaruh lebih dominan dalam menurunkan kemiskinan dibandingkan dengan instrumen zakat. Eksistensi DOK tidak hanya sebagai predictor variable bagi kemiskinan, tetapi juga memoderasi pengaruh negatif zakat terhadap kemiskinan. Interaksi antara penerimaan zakat dan DOK adalah positif dan signifikan dalam mempengaruhi penurunan kemiskinan di Aceh. Hal ini mengindikasikan bahwa DOK meningkatkan pengaruh penerimaan zakat dalam mengurangi jumlah penduduk miskin di daerah tersebut.

Mengacu pada kesimpulan di atas, maka kebijakan teknis yang seharusnya dilakukan pemerintah Aceh dalam menurunkan kemiskinan melalui instrumen zakat dan DOK sebagai berikut.
1. Pengalokasian dana zakat kepada mustahiq zakat terutama fakir miskin sebaiknya dalam bentuk zakat produktif khususnya bagi mereka yang telah memiliki usaha. Penyaluran dana zakat tersebut dapat dalam bentuk bantuan alat-alat produksi dan modal kerja sehingga mampu memberikan nilai tambah bagi perkembangan usaha mereka. Namun demikian, penyaluran zakat konsumtif bagi mustahiq yang benar-benar membutuhkan tetap harus menjadi perhatian utama.

2. Pengalokasian DOK oleh pemerintah kabupaten kota di Aceh harus berorientasi pada pembangunan insfrastruktur publik yang dapat memberikan dampak jangka panjang bagi penurunan kemiskinan. Karena sebagian besar penduduk miskin adalah petani, maka penggunaan DOK tidak hanya diarahkan untuk mendukung perkembangan sektor tersebut, tetapi memprioritaskan infrastruktur fisik yang dapat memberikan manfaat lebih cepat bagi peningkatan taraf hidup petani, seperti irigasi, dan jalan desa yang memudahkan akses petani ke lahan pertanian mereka.

\section{Daftar Pustaka}

Abdelbaki, H. H. (2013). The impact of zakat on poverty and income inequality in Bahrain, Review Integrative Business \& Economy, 2(1),133-154.

Aisyah, M. (2014). The role of zakah and binary economics in poverty reduction, ESENSI: Jurnal Bisnis dan Manajemen, 4(2),178-197.

Ali, A. F. M., Rashid, Z. A., Johari, F., \& Aziz, M. R. A. (2015).The Effectiveness of Zakat in reducing poverty incident: An analysis in Kelantan, Malaysia, Asian Social Science, 11(21), 335-367.

Amri, K. (2014). Infrastruktur transportasi dan kepadatan penduduk dampaknya terhadap pendapatan per kapita: Panel Data Evidence dari sembilan provinsi di Sumatera, Jurnal Ekonomi Manajemen dan Bisnis, 2(2), 438450.

Amri, K. (2017a). Analisis pertumbuhan ekonomi dan ketimpangan pendapatan: Panel data 8 provinsi di Sumatera, Jurnal Ekonomi dan Manajemen Teknologi, 1(1), 111. 
Amri, K. (2017b). Indek harga konsumen dan belanja modal terhadap indek perilaku korupsi, SI-MEN (Akuntansi dan Manajemen) 8(1), 49-65.

Amri, K. (2018). The macroeconomic impact of regional minimum wages: A cross-province data evidence from Indonesia, Regional Science Inquiry, 10(3), 163-176.

Amri, K., \& Marwiyati. (2019). Preferensi muzakki membayar zakat melalui Baitul Mal: Studi empiris di kota Banda Aceh, Jurnal Manajemen dan Sains, 4(2), 386-391.

Amri, K., \& Aimon, H. (2017). Pengaruh pembentukan modal dan ekspor terhadap pertumbuhan ekonomi Indonesia, Economac 1(1), 1-16.

Amri, K., \& Nazamuddin. (2018). Is there causality relationship between economic growth and income inequality? Panel data evidence from Indonesia, Eurasian Journal of Economics and Finance, 6(2), 8-20.

Arie, M., Ilmar, A., Maskun., \& Bakti, F. P. (2017). The institutional arrangement of special autonomy fund management of Papua Province, Journal of Law, Policy and Globalization, 67, 79-83.

Ayuniyyah, Q., Pramanik, A. H., Saad, N. M., \& Arifin, M. I. (2018). Zakat for poverty alleviation and income inequality reduction: West Java, Indonesia, Journal of Islamic Monetary Economics and Finance, 4(1), 85 -100 .

Fanggidae, I. G., Fajri, H., \& Yuanjaya, P. (2016). Menelisik kinerja governance di daerah otonomi khusus Papua Barat, NATAPRAJA: Jurnal Kajian Ilmu Administrasi Negara, 4(1) 91- 106.

Faradisi, N. (2015). Determinan pertumbuhan ekonomi provinsi Aceh, Signifikan, 4(2), 151-172

Ghozali, I. (2011). Aplikasi Analisis Multivariate dengan Program IBM SPSS19. Semarang. Badan Penerbit Universitas Diponegoro.

Hoque, N., Khan, M. A., \& Mohammad, K. D. (2015). Poverty alleviation by Zakah in a transitional economy: A small business entrepreneurial framework. Journal of Global Entrepreneurship Research, 5(1), doi: 10.1186/s40497-015-0025-8
Isiaka, A. O., Johari, M., \& Alias, M. (2015). Is Zakah effective to alleviate poverty in a Muslim society?: A case of Kwara State, Nigeria, GJAT, 5(1), 1-9.

Johari, F., Aziz, M. R. A., \& Ali, A. F. M. (2014). The role of zakat in reducing poverty and income inequality among new convert (muallaf) in Selangor, Malaysia, Online Journal of Research in Islamic Studies 1(3), 43-56.

Khasandy, E. A., \& Badrudin, R. (2019). The influence of zakat on economic growth and welfare society in Indonesia, Integrated Journal of Business and Economics, 65-79, doi:10.33019/ijbe.v3i1.89.

Mohamed, A. S. Bin, Ibrahim, A. A. Bin, Zaidi, N. S. B., \& Kamaruzaman, M. N. Bin. (2019). Does zakat significantly impact on economic growth in Selangor, Malaysia? International Journal of Academic Research in Business and Social Sciences, 9(6), 786807.

Mubarokah, I., Beik, I. S., \& Irawan, T. (2017). Dampak zakat terhadap kemiskinan dan kesejahteraan mustahik (Kasus: BAZNAS provinsi Jawa Tengah), Jurnal AlMuzara'ah, 5(1), 37-50.

Muliadi, \& Amri, K. (2019). Infrastruktur jalan, belanja modal dan kesempatan kerja: Bukti data panel kabupaten kota di Aceh, Jurnal Manajemen dan Sains, 4(2), 334-341.

Murniati, R., \& Beik, I. S. (2015).Pengaruh zakat terhadap indeks pembangunan manusia dan tingkat kemiskinan mustahik: Studi kasus pendayagunaan BAZNAS kota Bogor, Jurnal Al-Muzara'ah, 2(2), 135-149.

Nurjanah, F., Kusnendi, \& Juliana. (2019). The impact of economic growth and distribution of zakat funds on poverty (Survey in the third district of West Java province period 2011-2016), KnE Social Sciences, 55-70. DOI 10.18502/kss.v3i13.4195

Redha, B. M., Larbi, G., \& Karima, R. M. (2016) The impact of zakat fund in reducing poverty, case of Algeria, Mediterranean Journal of Social Sciences, 7(3), 256-264.

Soejoto, A., Waspodo T. S., \& Suyanto. (2015). Fiscal decentralization policy in promoting Indonesia human development, International Journal of Economics and Financial Issues, 5(3), 763-771. 
Jurnal Ilmiah Ekonomi Islam, 5(03), 2019, 244

Tajuddin, I., Basri H., Rahmatia, \& Paulus, U. (2014). The effects of general allocation funds, special allocation funds and revenuesharing funds on investment, economic growth, economic structure, and employment, Journal of Research in Business and Management, 2(10), 54-61.

Undang-Undang RI No. 11 Tahun 2006 tentang Pemerintah Aceh.
Undang-Undang RI No. 18 tahun 2001 tentang Otonomi Khusus bagi Daerah Istimewa Aceh.

Zulham, T., Muhammad, S., Masbar, R., \& Sirojuzilam. (2015). The impact of special autonomy on the convergence of regional economic growth in Aceh, Indonesia, Aceh International Journal of Social Sciences, $4(1), 41-55$. 